\title{
AN OCCUPIED CHURCH?: \\ READING THE OCCUPY WALL STREET MOVEMENT ECCLESIOLOGICALLY IN CONVERSATION WITH NEW MONASTICS
}

\author{
Gregory P. Van Buskirk \\ Boston University, US \\ Email: greg.vanbuskirk@gmail.com
}

Submit: 16 November 2020 Revised: 20 May 2021 Accepted: 10 June 2021

\begin{abstract}
The church needs to challenge itself about its identity, constitution, and mission, because out of necessity this involves the world and the events that unfold in it. Thus, sociological, political, and economic issues have ecclesiological components and consequences that are practically tautological, including the Occupy Wall Street (OWS) movement. The question thus moves from whether the Church is called to critical reflection on OWS to how that critical reflection should occur. The purpose of this article is to point out the specific practice of the OWS movement - the "sign" - to be considered through an ecclesiological lens. The method used is from an ecclesiological lens with a new monastic. The results of this research are firstly, the church must actively and responsibly inculcate non-violent practices, communitarian economy, and embody space and place, while at the same time joining forces with nonecclesiastical organizations that support these practices. similar. Second, by whom - and by whom - the Church (as a very different polis) must always point beyond itself to what is its foundation and fulfillment. As long as the Church faithfully responds to this call, the Kingdom will be in our midst.
\end{abstract}

Keywords: church, wall street, ecclesiology, new monastics

\section{INTRODUCTION}

For as long as the Church has been called such, it has had to navigate the question of its identity, constitution, and mission - most often with regard to its relationship with the world. However the Church acts and responds to the society surrounding it at any given point in history, one fact remains constant: the world and its events matter to the Church. This also has a corollary: ecclesiology not only considers the nature, mission, organization, and identity of the Church; it also - by a matter of necessity involves the world and events that unfold within it. This is not to say that ecclesiology becomes some sort of overarching meta-hermeneutic; rather, as long as the Church is historically situated, history (broadly understood) matters. Therefore, claiming that issues of sociology, politics, and economics have ecclesiological components and ramifications is 
practically tautological. ${ }^{1}$

It is in this light that one approaches the above words of Jim Wallis - founder, CEO, and editor- in-chief of Sojourners magazine. Wallis is referring to the Occupy Wall Street movement that began September 17, 2011, in New York City, and has since grown into a worldwide movement protesting economic disparity and injustice. The Church cannot possibly ignore a movement of such magnitude - nor should it. As Wallis states above, the issues underlying the Occupy Wall Street (OWS) movement involve salvation, ethics, and faith - in a word, OWS has presented issues of the Kingdom of God, and therefore demands ecclesiological attention. The question thus moves from whether the Church is called to critical reflection about OWS to how that critical reflection should occur.

However, there is a glaring and inherent difficulty in this task: how does one identify the character of the OWS movement, and what sources are to be considered trustworthy in that process? The still-nascent movement has no official spokesperson; indeed, it is radically decentralized, which has also played into an understanding that the protesters' demands are widespread and lacking clarity. The situation is further complicated by the zeitgeist of modern news/media, which has capitalized on sensational, politicized reporting. That said, one must tread lightly concerning the sources used for such an analysis. One source will be reputable news organizations with well-defined journalistic ethics - National Public Radio, the New York Times, and the BBC. Another source will be the OWS movement itself, mediated through websites that present "official" OWS information (statements, propaganda, etc.). Included in these are websites for the New York City General Assembly ${ }^{2}$ and the unofficial website for Occupy Wall Street ("unofficial" due to the decentralized structure of the movement). ${ }^{3} \mathrm{~A}$ final source will be general observation itself, used only to sketch the movementbroadly.

Rather than identify or categorize the various ideologies underlying OWS, the intent here is to point to specific practices of the OWS movement - "marks" - to be considered through an ecclesiological lens. Specifically, there are three practices for consideration: nonviolence, communitarian economics, and the embodiment of space and

${ }^{1}$ Jim Wallis, "A Church Sanctuary for the Occupy Movement," God's Politics Blog, November 17, 2011, http://www.sojo.net/blogs/ 2011/11/17/church-sanctuary-occupy-movement, accessed Nov. 20,2011.

${ }^{2}$ www.nycga.net - representing the "first" OWS gathering [NYCGA].

${ }^{3}$ See www.occupywallst.org. 
place. First, I will analyze these practices, thereby claiming OWS as a movement with ecclesiological significance and implications for how the Church must understand itself. Second, I will engage in conversation with a variety of theological interlocutors, the foremost of which are those belonging to the "New Monastic Movement" (NMM). This is a deliberate choice: not only does the NMM see itself as embodying the same kinds of practices as OWS, it may be argued that the demographics of NMM and OWS overlap - and that this demographic (Gen X and Gen Y) tends to be lacking in modern mainline denominations. Furthermore, I will include other sources for ecclesiological conversation from throughout the Christian tradition: modern theologians and ethicists (Stanley Hauerwas, John Yoder, Mary McClintock Fulkerson), theologians and pastors from the Christian tradition (John Wesley, the Patristics), and Scripture. In the third and final section, I will make a strategic, pragmatic shift to consider what OWS may have to offer Christian practice. The argument here is that the three practices of OWS are ecclesiological and are evident throughout the Christian tradition. However, the Church is (and has been) reticent to embody them fully. As today's Church looks to the future, it is ever more necessary that it embraces its narrative tradition for the sake of fostering both personal and social holiness. In a word, the common practices of OWS and the NMM indicate an ecclesiological vision for how to maintain - and reclaim - vitality in the Church, especially considering the under-representation of 18-40 year olds in today's churches. Finally, it will be necessary to address the other direction in this conversation: not only what OWS may have to offer the Church, but also what the Church may have to offer OWS. Proper critical reflection requires this dialogical contour.

\section{METHODS}

Reading the occupy wall street movement ecclesiologically in conversation with new monastics. In this article, i begin to discuss the findings of Ecclesiological Analysis of Occupy Wall Street Practices, which in it discuss onviolence, communitarian economics, embodiment of space and place, and reading the three practices in Christian tradition. Then this topic continues on Systematic Ecclesiological Reflection in Dialogue with Contemporary Thinkers, namely nonviolence, communitarian economics, with embodied space and place. And in the 
final topic section, i propose a prescriptive recommendation for practice: a call for Church involvement in the OWS movement, an ecclesiology encompassing three practices, formation of Christian community, differentiating OWS and Church.

\section{RESULT AND DISCUSSION}

\section{An Ecclesiological Analysis of Occupy Wall Street Practices}

The Occupy Wall Street movement presents a challenging opportunity to today's Churches. Fundamentally, OWS is concerned with politics and economics, brought together under the umbrella of "power." One question facing the Church is how much it should be involved in politics and economics - or, more broadly, how involved the Church should be in "worldly affairs." John Wesley addresses this topic in his fourth of 13 sermons on Jesus' Sermon on the Mount: "[Consider] Much more the words of our Lord, who is so far from directing us to break off all commerce [i.e., interaction, engagement] with the world that without it, according to his account of Christianity, we cannot be Christians at all." By Wesley's account, one cannot be a Christian without engaging the world. As will be described later, Wesley himself was a strict adherent to this guiding principle.

Further insight into the conversation of the relationship between the Church and the world comes from Latin American liberation theologian Gustavo Gutiérrez, who critically argues that the hermeneutic bifurcation of history into "sacred" and "profane" is altogether a fallacy. Instead, "the salvific action of God underlies all human existence," 5 meaning that a division of "Church" and "world" is both artificial and theologically untenable. For Gutiérrez, sin permeates all aspects of life, and thus salvation understood as human liberation - has an immediate, this-worldly component. Therefore, everything - ecclesiology included - becomes political in the sense that it deals with issues of history, justice, and salvation. This comes out of Gutiérrez's "Conclusion":

The theology of liberation attempts to reflect on the experience and meaning of the faith based on the commitment to abolish injustice and to build a new society; this theology must be verified by the practice of that commitment, by active,

${ }^{4}$ John Wesley, Sermon 24, "Sermon on the Mount, IV," §I.6. Unless otherwise noted, references to Wesley are from the Bicentennial Edition of The Works of John Wesley (Nashville: Abingdon, 1984), edited by Albert C. Outler, et al.

${ }^{5}$ Gustavo Gutiérrez, A Theology of Liberation: History, Politics, and Salvation, (Maryknoll: Orbis Books, 1988), 86. 
effective participation in the struggle which the exploited social classes have undertaken against their oppressors. Liberation from every form of exploitation, the possibility of a more human and dignified life, the creation of a new humankind-all pass through this struggle. ${ }^{6}$

Therefore, ecclesiology - who the Church is and what the Church does - centers on intentional praxis rooted in an ethic that traces its way through Scripture and is most clearly revealed in Christ. This praxical focus legitimates a consideration of the three practices of OWS - nonviolence, communitarian economics, and the embodiment of space and place. First, I will describe each of them with examples. Then, I will consider them collectively, indicating how they bespeak an ecclesiological ethic likewise manifest in early Christianity.

\section{Nonviolence}

Undergirding the OWS protests is an ethic of nonviolence, similar to that which was portrayed in the American Civil Rights movement of the 1960s. It is explicit and intentional, as portrayed in the "Good Neighbor Policy" adopted by the NYCGA on October 13, 2011: "Zero tolerance for violence or verbal abuse towards anyone; Zero tolerance for abuse of personal or public property."7 This is again echoed in a number of videos (posted on occupywallst.org) that utilize the "human microphone"8 tactic in the call to nonviolent protest and occupation on November 17. Perhaps most telling is a poster distributed for this "N17" event (marking the two-month anniversary of OWS), seen to the right. ${ }^{9}$

However, this nonviolent ethic is not only claimed from within OWS; it has also been reported on by reputable news organizations. A number of articles from the New York Times cite the nonviolent ethic of OWS. ${ }^{10}$ One article cites the continuity between the

${ }^{6}$ Gustavo Gutiérrez, A Theology of Liberation: History, Politics, and Salvation, 174.

${ }^{7}$ New York City General Assembly, "Good Neighbor Policy," http://www.nycga.net/resources/goodneighbor-policy/, accessed Nov. 20, 2011.

8 The "human microphone," or "people's microphone," is a tactic for delivering speeches to a large group of people without the use of mechanical amplification. The speaker lines out a few words at a time, which are then "repeated" by the gathered group in "waves," as they are able to hear and reproduce the utterance. Thus, everybody at the gathering both hears and speaks the words of a speech.

9 By artist "r.black," whose only stipulation is that the posters may not be sold, only given away. Available at occupywallst.org.

10 "The protesters have shown a remarkable commitment and have stayed nonviolent in the face of aggressive actions by the New York police" - Erik Eckholm and Timothy Williams, "Anti-Wall Street Protests Spreading to Cities Large and Small," New York Times, October 3, 2011, 
Occupy movement and the protests of the Arab Spring from earlier in 2011: "Now, newcomers to Zuccotti Park are given leaflets explicitly connecting the movements: 'We are using the revolutionary Arab Spring occupation tactics to achieve our ends and we encourage the use of nonviolence to maximize the safety of all participants."'11 Additionally, reporting by the $\mathrm{BBC}^{12}$ and $\mathrm{NPR}^{13}$ has noted similar nonviolence amongst the protesters. These examples are but a few among many, but they reveal something crucial about the character of the OWS movement: it is explicitly nonviolent.

\section{Communitarian Economics}

Identifying this "mark" of the OWS movement requires much more observation and acknowledgement of the general ethos of the movement. Still, journalists reporting from the field have noted what I am here calling a "communitarian economics" - sharing resources and living in intentional community. Robert Hirschfield of Sojourners describes the New York scene:

Free pizza, apples, oranges, bread, and potato salad crammed the food table. There was a free outdoor barber shop. Even a free newspaper: The Occupied Wall Street Journal. On the ground was a paper plate with money on it. Around the edges of the plate was written: "If You Have Money Give Some. If You Need Money Take Some."14

http://www.nytimes.com/2011/10/09/us/in-chicago-banking-and-futures-industry-protests-planned.html, accessed Nov. 20, 2011.

Reporting on protesters urging one another to remain nonviolent may be seen in the following: Don

Terry, "Banking and Futures Industry Protests Planned," New York Times, October 8, 2011, http://www.nytimes.com/2011/10/09/us/in-chicago-banking-and- futures-industry-protests-planned.html, accessed Nov. 20, 2011; Kirk Johnson, "Occupy Protesters Regroup After Mass Arrest," New York Times, October 30, 2011, http://www.nytimes.com/2011/10/31/us/occupy-wall-street-protesters-arrested-indenver-and- portland.html, http://cityroom.blogs.nytimes.com/2011/11/08/protester-arrested-duringbomb-scare-evacuation/, accessed Nov. 20, 2011; Matt Flegenheimer, "Protesters Arrested During Bomb Scare Evacuation," New York Times, November 8, 2011, accessed Nov. 20, 2011.

11 Anne Barnard, "Occupy Wall Streets Meets Tahrir Square," New York Times, October 25, 2011, http://cityroom.blogs.nytimes.com/ 2011/10/25/occupy-wall-street-meets-tahrir-square/, accessed Nov. 20, 2011.

${ }_{12}$ Mark Mardell, "At the Scene," BBC News, November 15, 2011, http://www.bbc.co.uk/news/worldus-canada-15746013, accessed Nov. 20, 2011.

13 The Associated Press, "Occupy Movement Stays Peaceful in Cash-Poor Vegas," NPR, November 16, 2011, http://www.npr.org/ templates/story/story.php?storyId=142382571, accessed Nov. 20, 2011; The Associated Press, "Occupy Movement Debates How To Police Its Fringe," NPR, November 9, 2011, http://www.npr.org/templates/ story/story.php?storyId=142177901, accessed Nov. 20, 2011; The Associated Press, "Emotions Run High After Occupy Protests In Oakland," NPR, November 4, 2011, http://www.npr.org/ templates/story/story.php?storyId=142011377, accessed Nov. 20, 2011.

${ }^{14}$ Robert Hirschfield, "American Spring?: Finding connections between the past, present, and future 
In a published form of a speech given in New York on October 6, columnist and award-winning journalist Naomi Klein echoes this sentiment:

That is what I see happening in this square. In the way you are feeding each other, keeping each other warm, sharing information freely and providing health care, meditation classes and empowerment training. My favorite sign here says, "I care about you." In a culture that trains people to avoid each other's gaze, to say, "Let them die," that is a deeply radical statement. ${ }^{15}$

To these accounts may be added general observations of the practices and ethos of OWS. Though the movement has been polyphonic in its demands, there is little doubt that the protesters are decrying the inequitable distribution of wealth, such that a concentrated few control the majority of the nation's (and the world's) resources. To these ends, protesters have established intentional tent- communities wherein an economics of reciprocity and egalitarianism is manifest. Across the nation, one may kitchen-tents, tents devoted to personal health and hygiene, public "library" tents, workshops for job-placement and housing, and "community purses." As a means of denouncing the consolidation and individualization of wealth, protesters are establishing intentional communities of sharing.

\section{Embodiment of Space and Place}

This final characteristic comes across so obviously that observation itself is the primary resource needed to identify it. Clearly, the movement deals with space and place, as given by its name: Occupy. The protest centers upon physically occupying a location and living there as an embodied community. For some, the community is a necessity - they have nowhere else to live; for others, it is a choice - they choose to live in a community of protest. What they hold in common is a protest that aims at being seen, heard, and felt - a presence that cannot be ignored. By placing themselves in economic centers, OWS protesters make a nonverbal yet embodied statement that seeks self-demarginalization.

But the embodiment of space and place is also an act of creation. In "An Open

at Occupy Wall Street," Sojourners, December 2011, 47.

15 Naomi Klein, "Occupy Wall Street: The Most Important Thing in the World Now," The Nation, October 6, 2011, http:// www.thenation.com/article/163844/occupy-wall-street-most-important-thingworld-now, accessed Nov. 20, 2011. 
Letter to Occupy Wall Street," Jim Wallis writes, “The new safe spaces you have created to ask fundamental questions are helping to carve out fresh societal space to examine ourselves-who we are, what we value most, and where we want to go from here."16 Naomi Klein addresses this, as well: "Yesterday, one of the speakers at the labor rally said: 'We found each other.' That sentiment captures the beauty of what is being created here. A wide-open space (as well as an idea so big it can't be contained by any space) for all the people who want a better world to find each other."17 Even the method that Klein used to address the OWS crowd bespeaks the embodiment of the movement: the "human microphone" relies on physical presence and human-generated acoustics on a grand scale. However, the embodied, localized nature of the movement also carries a major drawback: as winter approaches, the physical sustainability of a group living outdoors in tents is called into question. Nonetheless, this point serves to underscore the fact that the Occupy movement is - necessarily - embodied and placed.

\section{Reading the Three Practices in Christian Tradition}

Nonviolence, communitarian economics, and embodied place and space are nothing new within the Christian tradition - but they are becoming increasingly difficult to spot within today's churches. Therefore, when we (and I speak here as one within the Church) see non-ecclesial groups espousing practices resonant with Christian tradition and view these groups and these practices as something "other," unable to locate ourselves within them, we then signal to ourselves a clarion call to deeper reflection upon our own ecclesial narratives. Specifically, the claim being made is that the Church's reaction to OWS should not be one of rejection or alarm, but rather one of solidarity both in terms of the causes being championed and the methods being employed. This is because common causes and methods are rampant within the fullness of Christian tradition - particularly in its early formation.

Prior to Constantine, "nonviolence" and "Christian" went hand-in-hand. In the Epistle to Diognetus (c. 150-225), the apologist contemplates the motive for God sending Christ into the world, relating this to the nonviolent character that Christians are

\footnotetext{
${ }^{16}$ Jim Wallis, “An Open Letter to Occupy Wall Street," Sojourners, December 2011, 7.

${ }^{17}$ Klein, "Occupy Wall Street," The Nation.
} 
to adopt:

Was it then, as one might conceive, for the purpose of exercising tyranny, or of inspiring fear and terror? By no means, but under the influence of clemency and meekness. As a king sends his son, who is also a king, so sent He Him; as God He sent Him; as to men He sent Him; as a Savior He sent Him, and as seeking to persuade, not to compel us; for violence has no place in the character of God. [...] For it is not by ruling over his neighbors, or by seeking to hold the supremacy over those that are weaker, or by being rich, and showing violence towards those that are inferior, that happiness is found; nor can any one by these things become an imitator of God. But these things do not at all constitute His majesty. ${ }^{18}$

For the early Church, faith necessitated an ethic prescribed by the life and teachings of Jesus Christ, who himself led an example of nonviolence, both in word and in deed. In his Sermon on the Mount, Jesus teaches his disciples not to resist an evildoer or attacker, but instead to love one's enemy (Mt. 5:38-48). Again, one reads how Jesus instructs Peter to re-sheath his sword (Jn. 18:11), and how Jesus does not resist the violence of the police who attack him (Jn. 18:22). Hence, to embody the example of their rabbi, the early Christian community found it necessary to adopt an ethic of nonviolence, oftentimes in conflict with their national duty to serve in the military. The Church, being a foretaste of the coming Kingdom of God, thus had no place for violence.

The economics of the early Christian community also depicted a radical departure from that belonging to the culture surrounding it. This ethic actually predates the Christian community, as evidenced by these excerpts from the Torah (Lev. 19:9-10, NRSV; Lev. 19:33-34, NRSV; Lev. 25:35, NRSV). It is instructive that these lines come from Leviticus, the priestly book of the Torah, as they may be seen as a prefiguring of an ecclesiological ethic. Indeed, Jesus commands such a communitarian economics when he sends out his disciples "to proclaim the kingdom of God and to heal": "He said to them, "Take nothing for your journey, no staff, nor bag, nor bread, nor money - not even an extra tunic. Whatever house you enter, stay there, and leave from there'” (Lk. 9:2-4, NRSV).

As the early community was becoming "Church," it sought to maintain this communitarian economics. We read such an account in Acts 2: "All who believed were

18 Epistle to Diognetus 7:3-4; 10:5. In Ante-Nicene Fathers, ed. and trans. by Alexander Roberts and James Donaldson. 
together and had all things in common; they would sell their possessions and goods and distribute the proceeds to all, as any had need. Day by day, as they spent much time together in the temple, they broke bread at home and ate their food with glad and generous hearts, praising God and having the goodwill of all the people" (Acts 2:44-47a, NRSV). This tradition was continued for at least 150 more years, as indicated by Tertullian of Carthage's "Apology" (c. 197): "One in mind and soul, we do not hesitate to share our earthly goods with one another. All things are common among us but our wives." 19

Turning to the embodiment of space and place throughout the Christian tradition is more challenging (as it was with OWS) because it is so embedded within the narrative itself. The very covenant that God makes with Abram (Gen. 12:1ff.) is dependent upon progeny and proximity in the Promised Land. From there, the People of God struggled with place a place for worship (tabernacle, Temple, synagogue), a place away-from-home (exile), an occupied place (Roman occupation). If there was still any confusion about the importance of embodiment, of location, of situated-ness-in-history, the Incarnation removes it. As Gutiérrez writes, "Human history, then, is the location of our encounter with God, in Christ." 20 This is why Christian texts, such as the Epistles of John and 1 Corinthians 15, spill much ink combatting Gnosticism and teaching about the Incarnation. As the community of believers became "Church," greater attention was given to the placement of bodies within the congregation. The Apostolic Constitutions (c.375) details seating arrangement and church architecture as they pertained to an understanding of an embodied, placed Church. The common practice of establishing a church around a significant, memorable, or "holy" place further manifests the importance of location to the tradition.

Together, then, these three practices - nonviolence, communitarian economics, and embodied space and place - are thoroughly ecclesiological. While not to be understood as "marks of the Church" in the traditional sense, they may be seen as "emblematic practices" of the Christian community. As such, when we (as Church)

${ }^{19}$ Tertullian of Carthage, "Apology," In Ante-Nicene Fathers, ed. and trans. by Alexander Roberts and James Donaldson..

${ }^{20}$ Gutiérrez, A Theology of Liberation, 106. 
observe within the Church an abandonment of an ethic of nonviolence, communitarian economics, and embodiment of place ${ }^{21}$ - and when we see an adoption of these selfsame ethics elsewhere - it behooves the Church to arise from its slumber and to reclaim its identity in the form of its practices. Thus, in the turn to modern theological voices who have addressed these practices, it is imperative to read them in light of the practical ecclesiology they espouse, and how these practices are being embraced by OWS.

\section{Systematic Ecclesiological Reflection in Diaologue with Contemporary Thinkers}

The aim of this section is to be able to point to contemporary theologians who have addressed these three practices with regard to Christian social ethics (which is nothing less than "ecclesiology"). Our primary conversation partners will come from the New Monastic Movement for three reasons: first, their ethic is grounded in the Christian tradition - they are trying to live according to the historical examples lifted up in the previous section; second, their practices parallel those witnessed in the OWS movement; third, there is a great deal of demographic overlap between the NMM and OWS. In the course of this reflection, I will include the voices of Stanley Hauerwas and John Yoder, John Wesley, and Mary McClintock Fulkerson to deepen the conversation. Finally, consideration of the NMM will come from School(s) for Conversion: 12 Marks of a New Monasticism, a compendium of essays written by residents of the Rutba House in North Carolina - an intentional community for Christian spirituality.

\section{Nonviolence}

In his chapter addressing peacemaking and nonviolence, Fred Bahnson draws a crucial connection between nonviolence and its performance within the Christian community. For Bahnson, this first has to do with how the Church understands the Kingdom of God in contrast with what he calls a "militaristic idolatry": “...We've failed to

21 The loss of a nonviolent ethic can be seen in the support that Christians lent the "anti-terrorist" efforts surrounding September 11, 2001. Churches were (are) not immune to this complicit vengeance. The death of communitarian economics may be traced to the birth of "liberalism" and "capitalism" - of an "individualized economics" supported by social Darwinism. The loss of embodiment of place and space is a more-current challenge posed by this digital era in which it is not longer necessary to be present physically to have "community." 
see that the kingdom of God is a political reality. Our truncated gospel preached on any given Sunday tells us that the kingdom of God is located either in our hearts or at the end of time."22 Essentially, this is the root of the problem that Gutiérrez raises - how we fail to read salvation-history as one, as a unity of divine and human history, such that the reign of God occurs in this world and necessitates a Christo-centric ethic today. Also like Gutiérrez, Bahnson reads this politically: “Jesus' contrast-society was a polis, a new political reality." 23

The political reality and the real presence of the Kingdom is predicated upon a true community of believers devoted not only to "proclaiming the gospel message of peace and reconciliation," but who are "perform[ing] that message."24 "Community" and "performance" underscore liturgy ("the work of the people"), which is then the backbone of any ecclesiology - a Church who, quite literally, does life together. This life together, this ethic, is Christocentric: "Jesus didn't just preach about the peaceable kingdom of God, he embodied that kingdom. Jesus' life, death, and resurrection is a whole new social ethic for the people of God."25 Here, Bahnson adds yet another dimension to the practice: nonviolence not only takes shape in a community formed by Christ's life and teaching, it also must embody the peacemaking heart of nonviolence. Peacemaking necessitates community, not only in the sense presented in Matthew 18 (i.e., the community as ultimate authority for settling disputes), but also in the sense that our human practices inevitably affect the greater community. Hence, an ethic of nonviolence is simultaneously one of peacemaking, which, taken together, occur within the community of the people of God who do life together. Therefore, not only does Bahnson's chapter advocate this crucial ecclesiological ethic, his location - that he is writing from within the Rutba community - bespeaks the integration of these practices.

Bahnson furthers our dialogue when he quotes John Yoder: "The church's

22 Fred Bahnson, "Mark 11: Peacemaking in the Midst of Violence and Conflict Resolution Along the Lines of Matthew 18," in School(s) for Conversion: 12 Marks of a New Monasticism, ed. by the Rutba House (Eugene: Cascade Books, 2005), 152.

${ }^{23}$ Fred Bahnson, "Mark 11: Peacemaking in the Midst of Violence and Conflict Resolution Along the Lines of Matthew 18,"152.

${ }^{24}$ Fred Bahnson, "Mark 11: Peacemaking in the Midst of Violence and Conflict Resolution Along the Lines of Matthew 18,"151.

${ }^{25}$ Fred Bahnson, "Mark 11: Peacemaking in the Midst of Violence and Conflict Resolution Along the Lines of Matthew 18,"153. 
suffering, like the Master's suffering, is the measure of the church's obedience to the selfgiving love of God. Nonviolence is right, in the deepest sense, not because it works, but because it anticipates the triumph of the Lamb that was slain." 26 Here is the tie between the Kingdom, nonviolence and peacemaking, and cruciform suffering - all within the context of the community we call Church. Stanley Hauerwas pushes this one step further in his claim that the Church is to be, rather than to have, a social ethic: "They must be a people of virtue - specifically, the virtues necessary for remembering and telling the story of a crucified savior. They must be capable of being peaceable among themselves and with the world, so that the world sees what it means to hope for God's kingdom." 27 By addressing virtue, Hauerwas orients this ethical focus in two ways. Nonviolence (and peacemaking) is at once both a community and a social ethic: ${ }^{28}$ the Church (community) performs it for the sake of the world (society). As such, Hauerwas, Yoder, and Bahnson all locate nonviolence (more broadly understood to include "peacemaking") ecclesiologically: it is Christologically-rooted, presently-located, eschatologically-oriented, communally- embodied, and socially-performed.

Before moving on to communitarian economics, it is befitting to recall OWS, particularly how the practice of nonviolence is always a community performance. In fact, "nonviolence" proceeds from "community" insofar as "community" is the enactment and embodiment of an "identity" informed by practicing virtue. In a word, one cannot have "nonviolence" without "community." For the protesters, that community is OWS; for the New Monastics, Yoder, and Hauerwas, that community is the Church. The distinction between the two is significant, and will be treated in the final section of this paper. For now, suffice it to say that nonviolence is a product of community inasmuch as economics is. As such, I turn now to an ecclesiological reflection and conversation of communitarian economics.

\section{Communitarian Economics}

${ }^{26}$ John Howard Yoder, "Peace without Eschatology?" in The Royal Priesthood: Essays Ecclesiastical and Ecumenical, ed. Michael G. Cartwright (Scottdale: Herald Press, 1998), 151.

${ }^{27}$ Stanley Hauerwas, "The Servant Community: Christian Social Ethics (1983)," in The Hauerwas Reader, ed. John Berkman and Michael Cartwright (Durham: Duke University Press, 2001), 378.

28 "The question of violence is the central issue for any Christian social ethic" (Stanley Hauerwas, "The Servant Community: Christian Social Ethics, 390). 
Shane Claiborne, who writes the chapter on sharing economic resources in School(s) for Conversion, is what we might call a "living text" of the New Monastic practice of communitarian economics (as well as nonviolence and embodiment, for that matter). A founding member of The Simple Way in Philadelphia, PA, Claiborne also took up residence in its Community Center, which was destroyed by a seven-alarm fire on June 20, 2007, taking with it all of his possessions. ${ }^{29}$ Most telling was the community's response: within two days it had set up two relief funds for the fire victims. ${ }^{30}$ I offer this story as it is reflective of the practice of communitarian economics within the NMM, and as it serves as a practical example for what Claiborne describes in his chapter.

Claiborne fundamentally advocates a sharing of economic resources that takes root in relationality and a praxis of love. "The great tragedy in the church is not that rich Christians do not care about the poor," writes Claiborne, "but that rich Christians do not know the poor."31 Redistribution of wealth is "a form of simplicity rooted in love. [... It] is a description of what happens when people fall in love with each other across class lines."32 For an ecclesiological economics to take shape, there must be relationship entailing a community - in which people do not (and cannot) ignore the economic situations and needs of one another.

John Wesley succinctly captures this in his sermon entitled "On Visiting the Sick":

One great reason why the rich in general have so little sympathy for the poor is because they so seldom visit them. Hence it is that, according to the common observation, one part of the world does not know what the other suffers. Many of them do not know, because they do not care to know: they keep out of the way of knowing it—and then plead their voluntary ignorance an excuse for their hardness of heart. 'Indeed, sir' (said a person of large substance), 'I am a very compassionate man. But to tell you the truth, I do not know anybody in the world that is in want.' How did this come to pass? Why, he took good care to keep out of their way. And if

${ }^{29}$ Michael Matza, "Their Lives Shattered after Kensington Fire," The Philadelphia Inquirer, June 23, 2007, http://articles.philly.com/ 2007-06-23/news/24994323_1_kimberly-kensington-fire-fire-department, accessed Nov. 21, 2011.

30 Katie Stuhldreher, "Nonprofit Starts Two Relief Funds for Fire Victims," The Philadelphia Inquirer, June 22, 2007, http:// articles.philly.com/2007-06-22/news/24994254_1_relief-funds-funds-for-fire-victimscommunity-center, accessed Nov. 21, 2011.

${ }^{31}$ Shane Claiborne, "Mark 2: Sharing Economic Resources with Fellow Community Members and the Needy Among Us," in School(s) for Conversion, 28.

32 Shane Claiborne, "Mark 2: Sharing Economic Resources with Fellow Community Members and the Needy Among Us," in School(s) for Conversion, 29-30 
he fell upon any of them unawares, 'he passed over on the other side.'33

For Wesley and the peoples called Methodist, this wasn't just a message to be proclaimed; it was a lifestyle to be performed. An ethic of communitarian economics, of redistribution and care, was Wesley's practical mandate for disciples of Christ. Wesley's ministry thus included the following:

...feeding, clothing, housing the poor; preparing the unemployed for work and finding them employment; visiting the poor sick and prisoners; devising new forms of health care education and delivery for the indigent; distributing books to the needy; and raising structural questions about an economy that produced poverty. Wesley's turn to the poor, however, was not simply service of the poor, but more importantly life with the poor. [...] He actually shared the life of the poor in significant ways, even to the point of contracting diseases from their beds. [...] To be in Christ meant to take the form of Christ's own life for and with the poor. To be a disciple of Christ meant to be obedient to Christ's command to feed his sheep and to serve the least of his sisters and brothers. ${ }^{34}$

Wesley's “The Use of Money" illustrates (in Wesley's typical three-point fashion) how to consider this economic ethic in "three plain rules":

Gain all you can, without hurting either yourself or your neighbour, in soul or body, by applying hereto with unintermitted diligence, and with all the understanding which God has given you. Save all you can, by cutting off every expense which serves only to indulge foolish desire, to gratify either the desire of the flesh, the desire of the eye, or the pride of life. Waste nothing, living or dying, on sin or folly, whether for yourself or your children. And then, Give all you can, or in other words give all you have to God. [...] 'Render unto God', not a tenth, not a third, not half, but 'all that is God's.' 35

In Wesley, as well as in Claiborne, 36 the economics of the Church and the of the disciple is patterned after the new birth - the new society established in and by the community of faith, who embodies the ethics of the Kingdom and of Christ. Underlying the use of money in the Church-as- God's-community is a theological understanding of "enough" and of "gift." God has indeed created enough for us to live on, all of which is a gift from God. We are stewards of that gift, not proprietors.

33 Wesley, Sermon 98, “On Visiting the Sick," §I.3.

${ }^{34}$ M. Douglas Meeks, ed., The Portion of the Poor (Nashville: Kingswood Books, 1995), 10. Also cf. Wesley's injunction that this kind of ministry "is a duty which you cannot perform by proxy" (Wesley, Sermon 98, "On Visiting the Sick," §III.9).

35 Wesley, Sermon 50, “The Use of Money," §II.6.

${ }^{36}$ Claiborne, 32. 
Again, within the OWS community, the practice of communitarian economics stems forth from an essential reading of what it means to be and to live in community with one another. It would be impossible to share so radically, so authentically, without communing and communicating together - face-to-face, person-to-person. "Having all things in common" emerges from the recognition of human need in another and the ability to meet that need as self-in-community. However, as with "nonviolence," one will have to consider how OWS and the NMM locate this "community" differently.

\section{Embodied Space and Place}

With the NMM, embodiment of space and place is treated in terms of "relocation" with one another and of "proximity" to one another. Substantiating both understandings is the principle that "Church" is the present embodiment of the Kingdom of God. In her chapter addressing relocation, Sr. Margaret M. McKenna attends to relocating space and place that has been abandoned by empire. This becomes an interesting facet of the NMM when read against OWS: the former embraces the occupation of abandoned space; the latter embraces the occupation of...occupied space. The emphasis is significant: Sr. McKenna defines "abandoned place" as "one that has no attraction for the 'world of what's happening now, and therefore is left alone by the political, economic, and social powers that be." ${ }^{37}$ As prima facie, the Occupation of Wall Street may be considered the opposite of Sr. McKenna's point; however, the reading that is instructive for the purposes of this paper places an emphasis more on relocation. As such, consider Sr. McKenna's description of relocation:

Relocation expresses conversion and commitment, the decision to resist imperial pressures and the pleasures and rewards of conformity to the way of all empires: pride, power, and reduction of all values to the "bottom line." It is a coming out from under, a liberation and a real challenge. It is a no-saying and a yes-saying: No to an old way of life and Yes to the search for a new one. ${ }^{38}$

Sr. McKenna's accent on the desert experience helps to highlight the qualities of conversion and commitment expressed above. In a word, relocation expresses a transition of mind/soul/heart and body; it is a movement of one's physical being so as to be aligned with

\footnotetext{
${ }^{37}$ Sr. Margaret M. McKenna, "Mark 1: Relocation to Abandoned Places of Empire," in School(s) for Conversion, 15.

${ }^{38}$ Sr. Margaret M. McKenna, "Mark 1: Relocation to Abandoned Places of Empire," in School(s) for Conversion, 15.
} 
a transformation of identity and purpose. Relocating requires decisive, embodied action. As a material activity, it elevates the role of body within theology; as a community activity, it grounds body in the corporate Body of Christ. Insofar as relocation is a means of creating a physical community identity, it is an intentional spiritual practice.

Jon Stock's chapter in School(s) of Conversion approaches the topic of embodiment of space and place from a slightly different perspective - that of geographic proximity. In detailing his own choice to live in intentional community, Stock outlines the connection of identity to location: "We are trying to live in such a way that our identity as members of Christ's church is primary. Moving in order to be close to one another was a clear way of marking our new identity in Christ with his church."39 Because it is a choice, relocating proximally does not guarantee "community" or "identity"; rather, "proximity is a consequence of the purpose and mission of the church, especially in our day of rampant selfcenteredness." 40 For Stock, the pattern of this proximal community is the koinonia of the New Testament, which depicts "mutual participation" and "mutual indwell[ing]." ${ }^{11}$ As an embodied occupation of place, intentional community should reflect a corporate polity; as Sr. McKenna writes, "Personalist and communal rather than institutional models of organization will be characteristic." 42

Mary McClintock Fulkerson's Places of Redemption offers a constructive analysis of postmodern place theory that is worth considering in this conversation. This excerpt describes the postmodern shift to an epistemology of space:

Postmodern geography contests the modern concept of space as a vacuum-an infinite extension only to be measured or filled-and its implication that place is simply a site or pinpoint marker on that extension. In redefining place as a structure of lived, corporate, and bodied experience, such [postmodern] theories argue that place is primary and this modern concept of space is a secondary abstraction. When understood as bodied ingression into the world, place is truly fundamental in generating knowledge. ${ }^{43}$

\footnotetext{
39 Jon Stock, "Mark 9: Geographical Proximity to Community Members Who Share a Common Rule of Life," in School(s) for Conversion, 124.

40 Jon Stock, "Mark 9: Geographical Proximity to Community Members Who Share a Common Rule of Life," in School(s) for Conversion, 125.

${ }^{41}$ Jon Stock, "Mark 9: Geographical Proximity to Community Members Who Share a Common Rule of Life," in School(s) for Conversion, 127.

42 McKenna, "Mark 1," 21.

${ }^{43}$ Mary McClintock Fulkerson, Places of Redemption: Theology for a Worldly Church (Oxford: Oxford University Press, 2007), 25.
} 
Place and body are connected experientially and pedagogically; the act of physically relocating, whether as or to an intentional community, is but one method for focusing identity and character. McClintock Fulkerson summarizes with two implications of this place theory: first, "place is produced through practices [...] best understood as habitus"; second, "the social character of place has to do with its constant fluidity." 44 Here we see the inextricability of habituation and habitation: character, community, practices, and location must be considered an embodied unity. It is then no wonder why Hauerwas, who espouses habitus in his Christian social (virtue) ethics, understands the Church as "a community of character." 45 The community is "fluid" insomuch as it is consists of bodies - people whose embodied, experiential responses are always dynamic.

By this point, the connection to OWS should be clear: the movement's physical relocation and bodily occupation of space and place is a practice that bespeaks the character and identity of OWS. Though the original location - Wall Street, NYC - was intentional and particular, the now international scope of the movement affirms McClintock Fulkerson's argument for the constant fluidity of space.

Moreover, the protesters' utilization of the "human microphone" is perhaps the most practical example of what McClintock Fulkerson calls "resonances of communication": "While experience is a refracting medium, [...] a refracting medium that focuses experiences is bodies." ${ }^{46}$ The protesters' bodies quite literally shape their experience and place as their voices resonate together. Ultimately, space and place function in the OWS protests as a means for relocation, entailing a certain commitment and "conversion" to a common cause and way of life such that habitat prescribes habitus.

\section{Prescriptive Recommendations For Practice}

The ultimate reason for reading these three practices of OWS ecclesiologically has been to offer critically reflective and constructive recommendations for the future of

\footnotetext{
${ }^{44}$ Mary McClintock Fulkerson, Places of Redemption: Theology for a Worldly Church (Oxford: Oxford University Press, 2007), 35.

45 This phrase, of course, comes from the title of Hauerwas's book A Community of Character: Toward a Constructive Christian Social Ethic. (Notre Dame: University of Notre Dame Press, 1981).

${ }^{46}$ McClintock Fulkerson, 31.
} 
Christian praxis. I have spent time with Scripture and the Early Church to illustrate how the practices of nonviolence, communitarian economics, and embodied space and place are historically found within an authentic ecclesiology.

Furthermore, by placing the practices in dialogue with the New Monastics and other theologians, ethicists, and ecclesiologists, I have attempted to outline an ecclesiology that embodies these practices. However, it must be noted that Christian communities like the New Monastics are not representative of Christianity and the Christian Church as a whole. In fact, as was hypothesized earlier, there is a loose three-way correlation tying together OWS, the NMM, and the current state of mainline churches in America: OWS protesters have tended to belong to "Generation X" and "Generation Y" (18-45 year olds); the NMM, as an emblem of the "Emerging Church," has remained popular with a similar demographic; and mainline churches in America today have seen a reduction in this particular age range. ${ }^{47}$ These observations indicate a practical hypothesis of this paper: if churches (especially those in America) intend to continue into the future, they will have to (re)adopt the practices heretofore mentioned - nonviolence, communitarian economics, and embodied space and place. As I have attempted to demonstrate, this is nothing less than, in the words of John Yoder, letting the Church be the Church. The following recommendations stem from this fundamental hypothesis.

A call for the Church's involvement in the OWS movement. As mentioned earlier, this must move beyond "ministry to" to "solidarity with." The Church should not adopt an "us and them" mentality that somehow dichotomizes between "Church" and "OWS Protesters." There is a fine line to walk here since OWS is - decidedly - not the Church. Yet, the ecclesiological analysis of the above-described practices indicates the common concerns between Church and OWS. Consider these words from John Wesley in a sermon on

47 The demographics of OWS have been noted in all of the aforementioned articles describing the movement - so much so that, in his "Open Letter," Jim Wallis addresses the "young people," who are the movement. The NMM, while not ontologically identical with the "Emerging Church," is nonetheless an expression thereof. Accordingly, emergence has resonated most voluminously with Generations X and Y. Finally, mainline churches in America have been recognizing the "geriatricization" of the Church. My own denomination, the United Methodist Church, offers this "Demographic Snapshot" of the ages of its members: "18-29, 11\%; 30-49, 34\%; 50-64, 29\%; 65+, 26\% (SOURCE: Pew Forum on Religion \& Public Life)." (http://www.umc.org/site/apps/nlnet/content3.aspx? c=lwL4KnN1LtH\&b=2429873\&ct=5078325, accessed Nov. 22, 2011). 


\section{Kings 10:15:48}

Though we can't think alike, may we not love alike? May we not be of one heart, though we are not of one opinion? Without all doubt we may. Herein all the children of God may unite, notwithstanding these smaller differences.

These remaining as they are, they may forward one another in love and in good works. Surely in this respect the example of Jehu himself, as mixed a character as he was of, is well worthy both the attention and imitation of every serious Christian. ${ }^{49}$

More important than the political or religious affiliations of OWS members should be the causes they champion and the tactics they use to do it. The cause - economic justice - is a native concern to the People of God. The tactics - nonviolence, communitarian economics, and embodied space and place are native practices to the People of God. Both are traced as far back as Torah and as far forward as the eschaton. The call for ecclesial involvement in OWS is a call for the Church to live in solidarity with those whom Jesus came to serve.

An ecclesiology that embraces the three practices. It needs to be clear by now that nonviolence, communitarian economics, and the embodiment of space and place are already ecclesiological practices - albeit, mostly in a historical sense. Perhaps the greatest drawback of Constantinianism has been the conflation of the State's practices with the Church's - or, more properly, the conflation of the State's polity with the Church's. As Bahnson notes, the Church has already been given a polity in "Jesus' contrast-society." The vision of the Kingdom presented in Scripture is altogether peaceable; it is a community where none shall be in want; and, insofar as it understands itself to be the ingression of the Kingdom, the Church is necessarily embodied.

To embrace nonviolence ecclesiologically will mean that the Church must renounce the use of violence for itself and denounce the use of violence elsewhere. An understanding of "violence" must also extend to the language we use and the practices we employ; to be authentic, the true character of nonviolence must buttress the ethic of the community. Furthermore, nonviolence is not just the abandonment of violence; it is also the adoption of

48 "When [ Jehu] left there, he met Jehonadab son of Rechab coming to meet him; he greeted him, and said to him, 'Is your heart as true to mine as mine is to yours?' Jehonadab answered, 'It is.' Jehu said, 'If it is, give me your hand"' (NRSV).

${ }^{49}$ John Wesley, Sermon 39, "Catholic Spirit," ๆ 4-5. 
peacemaking. Peace supplants violence and becomes the positive assertion of the praxical character of the Church.

To embrace communitarian economics ecclesiologically will mean that the Church must reconsider how it uses its resources, capital, and assets. To what degree do churches "have all things in common," where members "sell their possessions and goods and distribute the proceeds to all, as any have need"? In what sense does this happen at a congregational level, a community level, and a worldwide level? Practically speaking, churches need to be engaged in the practices Jesus outlines in Matthew 25:31-46 - feeding, quenching, clothing, welcoming, visiting, and healing. But this cannot happen, in Wesley's words, "by proxy"; nor can it happen without true fellowship and community. To uphold a communitarian economics will mean that the Church must engage one another so as to feel genuinely one another's needs.

Therefore, to embrace the embodiment of space and place ecclesiologically will mean that the Church must physically gather together, occupying the world as members - as an embodiment - of the Kingdom. This does not necessitate church buildings, which often times drain church funds at the expense of embodied ministry. Rather, it emphasizes the mutuality, reflexivity, and indwelling of koinonia among those gathered. Again, this will have to affect the Church's words and deeds alike: language (especially in preaching and exhortation) must recognize and celebrate embodiment since members are of Christ's Body; practices need to affirm the created world - both human and nonhuman. Finally, proximal mutuality must yield essentially "horizontal" and servant-like organizational structures.

The formation of Christian community. At the heart of the recommendations offered herein resides a fundamental creation of Christian community. For both the NMM and OWS, place matters, especially as it comes to be the embodiment of faith and community. The three practices have no merit without community; in fact, they are impossible without community. However, what "community" means needs to be detailed and differentiated.

The pattern of community in the NMM and OWS reveals something far more radical than what is seen in most congregations today; it seeks to embrace sharing life together in a common location formed by a common ethic. Community thus entails a habitat of habitus. In 
an age when we can connect electronically with anyone in the world with just a few clicks on an iPhone, or when we can circumnavigate the globe in a jet plane in less than a day, the genuine fellowship of habitative communities gains ever more significance - both in terms of meeting a human need and in terms of delineating a specific narrative and set of practices unique to the Church.

Such a consideration of "narratives" is important: narratives create polities, which then promote practices and virtues - that which is called habitus. Oftentimes, the Church forgets that the cultivation of virtue is a task to which it has been prescribed by means of the story that constitutes its peoplehood and its practices. One way or another, all people become habituated; the question facing the Church is whether this habituation occurs within an ecclesial habitat, or if it is relegated to other spheres of existence. Since a part of ecclesiological habituation needs to include an affirmation of embodiment and human need, the proximity and inter-activity of the community is paramount.

In a very real sense, this is a call for the Church to live together - to blur the "boundaries of habitation" so that its existence is the New Creation. Living together underscores the interdependence for one another and for God, which is indispensible for a vital ecclesiology. Ipso facto, this Christologically-patterned community will embrace the practices of nonviolence, communitarian economics, and the embodiment of space and place (among others). In a community such as this, sanctuaries can finally become what they were intended to be: sanctuary.

Differentiating OWS and the Church. By means of conclusion, it is necessary to draw out this fourth and final recommendation for the future of Christian practice. In a word, OWS is not the Church (or the NMM). Ontologically speaking, OWS maintains a different narrative than does the Church - though the practices overlap. The difference does not make the Church's enactment of any given practice "better," lest the Church develop any sort of "superiority complex," which would be antithetical to its Christoformity. Rather, from an ecclesiological perspective, similarities of practice may be read as human responses to the gracious invitation of God at work everywhere and in all people.

There is also a confessional difference between OWS and the Church. As Yoder explains, "The definition of the gathering of Christians is their confessing Jesus Christ as 
Lord," whereas "the members of the other group do not."50 We cannot deny the fact that Christians are among the OWS protesters; however, a Christian presence does not somehow "baptize" the movement. To complicate matters, if OWS were to become a "Christian movement," it would still retain the practices outlined in this paper; in a word, it would likely look "the same."

The Church's confession in the lordship of Christ also raises a teleological difference. One of the major critiques of OWS is how it lacks specificity in its demands. This may be due to its openness to all people, such that "a lack of specificity" is really "a multiplicity" of demands. Either way, the question hovering among critics and by-standers alike is, "How will we know - how will they know - when it's 'over'?" In other words, What is the movement's telos? This is a great question that is impossible to answer authentically. But here is where one can see the Church's uniqueness: the Church is ontologically different because, in its Christological confession, it is oriented towards a particular telos - the Kingdom of God prefigured in the words and deeds of Jesus Christ.

\section{CONCLUSION}

Earlier, we pointed to Gutiérrez's reading of a unified history, the "setting" for human-divine interaction. With this reading comes an understanding that history must end at some point. But, in the Church's confession, the end of time (the eschaton) is a source of hope, a restoration of right-relationship with God and with one another. Gutiérrez writes, "Hope thus emerges as the key to human existence oriented towards the future, because it transforms the present." ${ }^{1}$ And again: "The hope which overcomes death ["sin"] must be rooted in the heart of historical praxis; if this hope does not take shape in the present to lead it forward, it will only be an evasion, a futuristic illusion." ${ }^{2}$ As Church, our past narratives and our future identity prescribe our present involvement in participating in the birthing of the New Creation. This is the end toward which the Church works; this is its particularity.

Therefore, the OWS movement presents the Church with two powerful messages,

\footnotetext{
${ }^{50}$ Yoder, "Why Ecclesiology is Social Ethics," in The Royal Priesthood, 108.

${ }^{51}$ Gutiérrez, A Theology of Liberation, 123.

52 Gutiérrez, A Theology of Liberation, 124.
} 
both uttered in the same breath. First, the Church must actively and responsibly incarnate the practices of nonviolence, communitarian economics, and embodied space and place, while at the same time joining forces with non-ecclesial organizations espousing similar practices. Second, based on who it is - and whose it is - the Church (as a radically different polis) must always point beyond itself to that which is its foundation and its fulfillment. Inasmuch as the Church faithfully responds to this call, the Kingdom will be in our very midst.

\section{REFERENCE}

Bahnson, Fred. "Mark 11: Peacemaking in the Midst of Violence and Conflict Resolution Along the Lines of Matthew 18," in School(s) for Conversion: 12 Marks of a New Monasticism, ed. by the Rutba House Eugene: Cascade Books, 2005.

Barnard, Anne. "Occupy Wall Streets Meets Tahrir Square," New York Times, October 25, 2011, http://cityroom.blogs.nytimes.com/2011/10/25/occupy-wall-street-meetstahrir-square/, accessed Nov. 20, 2011.

Claiborne, Shane. "Mark 2: Sharing Economic Resources with Fellow Community Members and the Needy Among Us," in School(s) for Conversion: 12 Marks of a New Monasticism, ed. by the Rutba House Eugene: Cascade Books, 2005.

Eckholm, Erik \& Williams, Timothy. "Anti-Wall Street Protests Spreading to Cities Large and Small," New York Times, October 3, 2011, http://www.nytimes.com/2011/10/09/us/in-chicago-banking-and-futuresindustry-protests-planned.html, accessed Nov. 20, 2011.

Flegenheimer, Matt. "Protesters Arrested During Bomb Scare Evacuation," New York Times, November 8, 2011, accessed Nov. 20, 2011.

Fulkerson, Mary McClintock. Places of Redemption: Theology for a Worldly Church. Oxford: Oxford University Press, 2007.

Gutiérrez, Gustavo. A Theology of Liberation: History, Politics, and Salvation. Maryknoll: Orbis Books, 1988.

Hauerwas, Stanley. "The Servant Community: Christian Social Ethics." in The Hauerwas Reader, ed. John Berkman and Michael Cartwright. Durham: Duke University Press, 2001. 
Hirschfield, Robert. “American Spring?: Finding connections between the past, present, and future at Occupy Wall Street," Sojourners, December 2011.

Johnson, Kirk. “Occupy Protesters Regroup After Mass Arrest,” New York Times, October 30, 2011, http://www.nytimes.com/2011/10/31/us/occupy-wall-street-protestersarrested-in-denver-and-

portland.html, http://cityroom.blogs.nytimes.com/2011/11/08/protester-arrested-during-bombscare-evacuation/, accessed Nov. 20, 2011.

Klein, Naomi. "Occupy Wall Street: The Most Important Thing in the World Now," The Nation, October 6, 2011, http://www.thenation.com/article/163844/occupy-wallstreet-most-important-thing-world-now, accessed Nov. 20, 2011.

McKenna, Sr. Margaret M. "Mark 1: Relocation to Abandoned Places of Empire," in School(s) for Conversion: 12 Marks of a New Monasticism, ed. by the Rutba House Eugene: Cascade Books, 2005.

Mardell, Mark. "At the Scene," BBC News, November 15, 2011, http://www.bbc.co.uk/news/world-us-canada-15746013, accessed Nov. 20, 2011.

Mathetes. “Epistle to Diognetus 7:3-4; 10:5." In Ante-Nicene Fathers. Volume 4: Tertullian, Part Fourth; Minucius Felix; Commodian; Origen, Part First and Second, ed. Alexander Roberts and James Donaldson. Revised and Chronologically arranged with brief prefaces and occasional notes by A. Cleveland Coxe. New York: Christian Literature Publishing Co., 1885. https://oll.libertyfund.org/title/coxe-ante-nicenefathers-volume-4.

Matza, Michael. "Their Lives Shattered after Kensington Fire," The Philadelphia Inquirer, June 23, 2007, http://articles.philly.com/2007-06-23/news/24994323_1_kimberlykensington-fire-fire-department, accessed Nov. 21, 2011.

Meeks, M. Douglas. ed. The Portion of the Poor. Nashville: Kingswood Books, 1995.

New York City General Assembly. Good Neighbor Policy." http://www.nycga.net/resources/good-neighbor-policy/, accessed Nov. 20, 2011.

Stock, Jon. "Mark 9: Geographical Proximity to Community Members Who Share a Common Rule of Life." in School(s) for Conversion: 12 Marks of a New Monasticism, ed. by the Rutba House Eugene: Cascade Books, 2005.

Stuhldreher, Katie. "Nonprofit Starts Two Relief Funds for Fire Victims," The Philadelphia 
Inquirer, June 22, 2007, http:// articles.philly.com/2007-0622/news/24994254_1_relief-funds-funds-for-fire-victims-community-center, accessed Nov. 21, 2011.

Terry, Don. "Banking and Futures Industry Protests Planned," New York Times, October 8, 2011, http://www.nytimes.com/2011/10/09/us/in-chicago-banking-and-futuresindustry-protests-planned.html, accessed Nov. 20, 2011.

The Associated Press, "Emotions Run High After Occupy Protests In Oakland," NPR, November $\quad 4, \quad 2011, \quad$ http://www.npr.org/ templates/story/story.php?storyId=142011377, accessed Nov. 20, 2011.

The Associated Press, "Occupy Movement Debates How To Police Its Fringe," NPR, November $\quad 9, \quad 2011, \quad$ http://www.npr.org/templates/ story/story.php?storyId=142177901, accessed Nov. 20, 2011.

The Associated Press, “Occupy Movement Stays Peaceful in Cash-Poor Vegas," NPR, November 16, 2011, 2 $\quad$ http://www.npr.org/ templates/story/story.php?storyId=142382571, accessed Nov. 20, 2011.

United Methodist Church. "Demographic Snapshot." Pew Forum on Religion \& Public Life. http://www.umc.org/site/apps/nlnet/content3.aspx?c=lwL4KnN1LtH\&b=2429873 \&ct $=5078325$, Accessed Nov. 22, 2011.

Wallis, Jim. "A Church Sanctuary for the Occupy Movement," God's Politics Blog, November 17, 2011, http://www.sojo.net/blogs/2011/11/17/church-sanctuary-occupymovement accessed Nov. 20,2011.

Wallis, Jim. “An Open Letter to Occupy Wall Street,” Sojourners, December 2011.

Wesley, John. Unless otherwise noted, references to Wesley are from the Bicentennial Edition of The Works of John Wesley. edited by Albert C. Outler, et al. Nashville: Abingdon, 1984.

Yoder, John Howard. "Peace without Eschatology?" in The Royal Priesthood: Essays Ecclesiastical and Ecumenical, ed. Michael G. Cartwright. Scottdale: Herald Press, 1998. 